\title{
Vrais Amis: \\ Reconsidering the Philosophical Relationship Between Foucault and Deleuze
}

\author{
CHRISTIAN GILLIAM \\ University of Surrey, Great Britain
}

\begin{abstract}
In the current literature addressing the Foucault/Deleuze relationship, there is a clear tendency to either replicate and expand Foucault's over-simplified rejection of Deleuzian desire as already caught in a discursive trap or play of power; or to replicate Deleuze and Guattari's over-simplified reading of Foucault's dispositif, in which power and resistance are deemed opposed and thus understood via a structure of negativity. In either case, each thinker is accused of referring to an asocial or essentialist multiplicity, typically in the form of a real transcendence (positive Body), which is deemed 'inconsistent' with their post-structuralist yearnings. This article argues that there is in fact a real and enduring consistency between the two thinkers, which is to be found in the mutual use of an ontology of 'pure' or 'disjunctive' immanence - as derived from and developed through Nietzsche's method of genealogy - as a way to construe power/subjectification, with pleasure/desire taken as the affective inside of this power. That said, the somewhat semantic difference between desire and pleasure being proposed does lead to a slight, though tangible, divergence in politico-ethical and practical possibilities. This article concludes that it is this divergence that should from the real basis of debate.
\end{abstract}

Keywords: Foucault, Deleuze, desire, pleasure, micropolitics, resistance.

\section{INTRODUCTION}

According to Foucault "where there is desire the power relation is already present: an illusion, then, to denounce this relation for a repression exerted after the event; but vanity as well to go questioning after a desire that is beyond the reach of power." ${ }^{1}$ It is precisely for this reason that freedom cannot be understood as the liberation of desire, as the liberation of an essential self as encapsulated in desire, nor as the simple negation of a repressive power. Indeed, Foucault famously proposes freedom as an aesthetical prac-

${ }^{1}$ Michel Foucault, The Will to knowledge: The History of Sexuality: Volume One [1978] (1998), 151. 
tice, a fluid and creative process, operating through power-relations by way of "bodies and pleasures." ${ }^{2}$ Foucault avoids the language of desire precisely because it seems to evoke a psychoanalytic idealism of lack and repression (contra his reversal of the repression hypothesis as presented in the first volume of The History of Sexuality), and in the same vein some sort of discursive fiction or essentialism that ultimately leads to a negative concept of power incompatible with his relational concept. Foucault's contemporary, Gilles Deleuze, explicitly construes desire as the affective, relational and agentic site through which aesthetical practices and ethical (re)negotiation can be articulated. Despite a number of apparent 'post-structuralist' continuities between Foucault and Deleuze, this appears to present a misalliance between them on the question of affectivity and its relation to power.

Deleuze himself comments that it is telling that Foucault is more interested in Sade, whereas he is more interested in Masoch. ${ }^{3}$ Allegedly, this portrays a difference that is certainly "more than a matter of vocabulary." ${ }^{4}$ What is striking is the fact that the misalliance has received little attention from critics and sympathetic commentators alike. ${ }^{5}$ What is also true, however, is that of the few who do directly pay attention to the apparent misalliance, there is a clear tendency to either replicate Foucault's rejection of desire as already caught in a discursive trap or play of power ${ }^{6}$ and his related suspicion of Deleuzian desire; ${ }^{7}$ or to replicate Deleuze and Guattari's over-simplified reading of Foucault's assemblage, in which power and resistance are deemed opposed and thus understood via a structure of negativity. ${ }^{8}$

Regarding the former interpretation, thinkers such as Judith Butler and Wendy Grace essentially argue that by virtue of retaining desire as a primordial 'micro' essence or presocial multiplicity, Deleuze ends up viewing power as a negative force concomitant with the macro-level or macro-political. ${ }^{9}$ It follows from this that ethical resistance - what Deleuze and Guattari refer to as becoming a Body without Organs $(\mathrm{BwO})^{10}$ - concerns liberating this desire from the repressive effects of the macropolitical and macropolitical institutions, i.e. the State. With such a reading, Deleuze is said to be led right back into

\footnotetext{
2 Ibid., 157.

${ }^{3}$ Gilles Deleuze, "Desire and Pleasure," in Two Regimes of Madness, ed. David Lapoujade [2001] (2007), 131.

4 Ibid., 130.

5 Wendy Grace, "Faux Amis: Foucault and Deleuze on Sexuality and Desire”, Critical Inquiry, 36:1, (2014), 54.

${ }^{6}$ Foucault, The Will to Knowledge, 151.

7 Michel Foucault, "Structuralism and Post-structuralism", in Michel Foucault: Aesthetics: Essential works of Foucault 1954-1984, ed. James. D. Faubion, ed. (2000), 446.

${ }^{8}$ Giles Deleuze and Felix Guattari, A Thousand Plateaus: Capitalism and Schizophrenia, 585n. 39. Interestingly, this reading is dropped by the time Deleuze comes to write Foucault [1986] (2006).

9 Judith Butler, Subjects of Desire: Hegelian Reflections in Twentieth-Century France [1987] (2012), 214-220; Wendy Grace, Faux Amis, 71-73.

${ }^{10}$ It is more broadly defined as the plane of immanence or the differential virtual prior to its actualised expressions. It is related to ethical resistance, in that the ideal is to release the virtual from its captured expressions in the actual, or at least to tend to the virtual so as to effectuate new expressions.
} 
the very Marxian-Freudian repression hypothesis that Foucault painstakingly dissected as a production of modern power itself. ${ }^{11}$ Since this vision of repression speaks to the political theory of old, in which power is 'anti-energy' and freedom the negation of this energy, those with poststructuralist leanings are left without any ambivalence as to who to favour in this debate. ${ }^{12}$

Regarding the latter interpretation, Deleuze sympathisers, particularly Hardt and Negri, have replicated and expanded Deleuze and Guattari's contention that it in fact Foucault who reinstates an outmoded negativity by opposing power to resistance. ${ }^{13}$ Broadly speaking, this reading has linked in with, and certainly reinforces the caricature of Foucault as an heir to Althusser, inasmuch as he is interpreted as utilising concepts concerned with the way in which power serves to 'fix' social identities through individualising practices that are both discursive and institutional. That is, to view Foucault as abiding by some sort of Althusserian theory of interpretation. ${ }^{14}$ This has opened the path for others to criticise Foucault on the grounds of incoherency, i.e. given that power is an omnipotent and productive force, it is unclear how resistance would take effect without evoking a positive Body (pleasure as an essentialism) discordant with Foucault's ontology. ${ }^{15}$ Other scholars have, in addition to these charges, argued that Foucault's account of power lacks interiority or any substantial consideration for affectivity. ${ }^{16}$

If ever there were an instance of two people 'speaking past each other', this is surely it. Secondary literature has continued to follow and in turn amplify this 'speaking past each other', resulting in a number of contrived and exceedingly confused exchanges and

\footnotetext{
${ }^{11}$ A similar point is made by Slavoj Žižek, Bodies without Organs: On Deleuze and Consequences (2012), 28; see also Steven Best and Douglas Kellner, Postmodern Theory: Critical Interrogations (1991), 106.

12 Butler (Subjects of Desire, 220) claims that in replacing Deleuze's 'precultural ontology' of desire within a theory of power-knowledge, Foucault brings to light the discursive limits of Deleuze's position, thereby sharpening his "challenge to psychoanalysis."

${ }^{13}$ Hardt and Negri, Empire (2000), 24 and 27-6.

${ }_{14}$ Slavoj Žižek, The Ticklish Subject: The Absent Centre of Political Ontology (1999), 296; Judith Butler, The Psychic Life of Power: Theories in Subjection (1997), 2, 5 and 99; John McCumber, Time and Philosophy: A History of Continental Thought (2011), 328-9; Mark Olssen, Michel Foucault: Materialism and Education (2006), 30; Karlis Racevskis, Michel Foucault, Rameau's nephew and the question of identity, in James Bernauer and David Rasmussen (eds.) The Final Foucault (1991), 23; and Richard Wolin, The Seduction of Unreason: The Intellectual Romance with Fascism, from Nietzsche to Postmodernism (2004), 13. Michael Hard and Antonio Negri, Empire, 24. For a targeted response to these claims, see Nathan Widder, "Foucault and Power Revisited", European Journal of Political Theory, 3:4, (2004), 411-432.

${ }^{15}$ For instance, Slajov Žižek, The Ticklish Subject, 296. Although Judith Butler (Gender Trouble: Feminism and the Subversion of Identity (2006), 132) appears to acknowledge that resistance is internal to Foucauldian power, she argues that Foucault himself is inconsistent on this account: "Foucault wants to argue that there is no 'sex' in itself which is not produced by complex interactions of discourse and power, and yet there does seem to be a 'multiplicity of pleasures', in itself which is not the effect of any specific discourse/power exchange." See also Wolin, The Seduction of Unreason, 19; and Jürgen Habermas, The Philosophical Discourses of Modernity (1987), 282.

${ }^{16}$ See for instance Nik Farrell Fox, The New Sartre: Explorations in Postmodernism (2003), 5; and Hardt and Negri, Empire, 28 and 422n. 14.
} 
theoretical straw men. ${ }^{17}$ The conceptual truth - as in the logical consistency of the conceptual framework as opposed to the transcendent Truth - as I wish to present it, could not be further from these readings. There is in fact a real and continuous consistency - or alliance - between Foucault and Deleuze; such that we can view their philosophical relationship in terms of 'vrais amis', as opposed to 'faux amis'. ${ }^{18}$ The difference between power-knowledge (with pleasure as the favoured affective term) and Deleuze's micropolitics (with desire as the favoured affective term), should be viewed and understood as more a matter of semantics. ${ }^{19}$

The consistency is to be found on the ontological level. Both thinkers adopt and argue for an ontology of 'pure' immanence, with particular reference to Nietzschean genealogy. Ultimately, 'pure' immanence provokes and in turn is employed as a way to construe a concept of power/subjectification as a non-essentialist and non-dialectical relation, with pleasure/desire taken as the affective inside of this power. Thus in referring to a 'semantic difference', I am referring to ontic, or rather non-ontological differences concerning expressive and linguistic preference and emphasis vis-à-vis affectivity. What is more, it is precisely due to 'pure' immanence as understood by Deleuze/Foucault that broader questions regarding their views on ethical resistance can be readdressed and in turn, reconsidered. The point here is not to embark on the reconsideration itself, which would result in - if not verge on - a definitive though unsatisfactorily limited resolution (given the finitude of the present paper). The point, rather, is to provide the conceptual basis for such a reconsideration.

It is evident that my reading of Deleuze and Foucault in this paper is systematic, viewing their overriding ontological contribution to subjectivity in terms of the 'disjunctive' as the defining synthetic feature of 'pure' immanence; and thematic, in that it identifies the development and exposition of this ontology as a theme present throughout their respective oeuvre's. The presence of the 'disjunctive' is not consistent in terms of conceptual labelling and context, though it is consistent in terms of progressive development, such that it is possible to provide a retrospective systematisation that links together the apparent discrepancy across their various works. And though not parallel in terms of pace, linear order and nature, the development of the 'disjunctive' can nevertheless be read as that which provides the fundamental link between Foucault and

\footnotetext{
17 Aside from the texts already mentioned, take for instance Mary Beth Mader, Sleights of Reason: Norm, Bisexuality, Development (2011), who seeks to overcome the apparent tension between Deleuzian desire and Foucauldian pleasure, through focusing on "normality," and "bi-sexuality," as points of union (p. 3); or Frida Beckman, Between Desire and Pleasure: a Deleuzian Theory of Sexuality (2013), 18, who takes the tensions highlighted as given, and from there seeks to uncover "what kind of energy is produced if we bring together these tensions."

${ }^{18}$ As characterised by Wendy Grace, see n. 9 .

${ }_{19}$ This would appear to vindicate Didier Eribon's (Michel Foucault (1992), 58-62), contention that the rift that existed between Deleuze and Foucault in the late 1970s was more a matter of politics than theory or philosophy; relating, for the most part, to the Klauss Croissant affair. Foucault sought to defend Croissant on the particular issue of rights, compared to Deleuze's defence of Klauss based on the more universal issue of revolutionary becoming. See also Steve Hendley, Reason and Relativism: A Sartrean Investigation (1991), 198.
} 
Deleuze. It provides, in other words, a more holistic ontology ${ }^{20}$ by which to trace lines of convergence and thus reposition the Foucault-Deleuze encounter.

\section{The Fold as Disjunctive Synthesis}

At its most basic, immanence refers to a state of being internal or remaining within, in which the condition (e.g. God) does not transcend, but rather is in the conditioned (e.g. sensuous existence). Rooted in the thought of Spinoza and the ancient Stoics on the nature of divinity, when applied to the formal structure of political subjectivity, it holds that the true cause of subjective and affective experience is in the effect, such that to isolate the one from the other is to enact a radical abstraction. Now, 'to remain within' might suggest some kind of harmonious unity or idealist interiority. ${ }^{21}$ What is significant about this 'pure' notion of immanence, however, is that despite superficial appearances it cannot be restricted to or defined in terms of 'complete' interiority, inclusivity or an apparent harmony between the conditions of experience and experience itself. 'Pure' immanence does in fact entail a notion of a socio-political Outside or Other and a corresponding excess or disturbance, a pluralisation of differences greatly exceeding the representational capacities of language and the large-scale contemporary forms of power that produce it. It is an Other radically reconfigured in terms of a fold of Being, as opposed to Hegelian holes of nothingness.

Following Deleuze's Foucault and The Fold, ${ }^{22}$ we can initially understand the fold in a literal manner, as in the folding of a piece of paper. Two marks on diagonally opposing corners of a piece of A4 paper may be distinguished by their negative difference, in that this primarily demarcates respective locations or identities. Unassuming as the point may seem, it is notable that the opposing marks are still of the same paper, for it is by virtue of this that if I were to fold one side of the paper over to the other, the two opposing marks would still retain their negative difference in one dimension, while gaining a closer connection in another. If this idea of folding is applied to multiple spatial dimensions, as we find in non-Euclidean $n$-dimensional space (and even multiple temporal dimensions), then we can image a highly complex relation of folds as a generative and constitutive process, which is always immanent unto itself without reference to a transcendent or external dimension. I can fold a piece of paper in multiple ways via multiple dimensions to generate new divergent relations between and within the marks on it. The folding can even serve to affect the form of the paper itself. In any case, the paper shall

20 'Holistic' in the sense that, given their ontological similitude, Deleuzian desire and Foucauldian pleasure can be read together so as to provide a fuller interpretation of the human experience.

${ }^{21}$ Some have read immanence in this fashion, e.g. Alain Badiou, Deleuze: The Clamor of Being (2000), p. 24 and Slavoj Žižek, Organs without Bodies: On Deleuze and Consequences, p. 25.

${ }^{22}$ The one monograph Deleuze dedicated to the fold (The Fold: Leibniz and the Baroque, [1988] (2006)) is in reality a monograph on Leibniz by way of the fold. Aside from a few references to the fold in his earlier works - (see for instance Deleuze Difference and Repetition, 76-8 and 125) - the only other occasion Deleuze explicates the fold is in his monograph on Foucault. But again, rather than engaging with an explication of the concept of the fold itself, it is employed instead as a means by which to conceptualise Foucault. 
remain. Opposition and/or correspondence between two things (such as the folded marks) may still exist. Yet, neither their opposition and/or correspondence are constitutive or conceptually holistic, since such opposition and/or correspondence will never delineate the multiple/other meanings, senses or differences that exist between and within the two things.

What is signified with this idea of a relational fold, then, is a "structural dissymmetry." 23 Constitutive differences of a being (e.g. the paper) are related through their difference, establishing intersections where differences resonate and communicate with each other and out of which temporary unities of identity and representation - as a moment of relational synthesis of intuitive-conceptual-ideal presentations - may arise. Such a folded relation can equally be dubbed, and indeed is dubbed, disjunctive since the resonance and communication of the disparate/ heterogeneous/ singular differences is not reducible to an Apollonian-Dionysian dichotomy between order and chaos, the summary law of all or nothing. In this dichotomy, differences are either collapsed into a higher unity (dialectical synthesis) of full positivity (identity) and thus assimilated into a singular and same logic, or collapse into a total and ineffectual non-relation, as full negativity (nothingness). ${ }^{24}$ In a disjunctive/folded synthesis, differences - of faculties, of signifiers, or discursive nodal points, of agents - relate without their difference being subsumed and thus the dichotomy is surpassed.

Congruent with my thematic and systemised account of Foucault and Deleuze, we can locate three types, or levels of folding within their works. There is a transcendental Inside of infinitesimal folds as interiority (self/ faculties), an Outside of infinitesimal folds as socio-political exteriority (Other) and a fold between the two (synthesis). Or, to put it differently, the Outside actual multiplicity is a folded synthesis that creates an Inside folded synthesis as in a virtual multiplicity of the infinitesimal self. The Inside in turn is folded back out or into the Outside, in what is a seemingly circular process of folding. The multiplicities form a continuum. Positing the differential fold as primary amounts to a reversal of Plato's emphasis on immutable positive identities underpinning a world of flux. For what we have here is a primacy of difference, of pure flux. Difference is primary, difference is affirmed, leading Deleuze to speak of 'vice-diction' as opposed to 'contradiction'. The reversal is not a perfect one, however, because with immanence there is no reference to a transcendent Outside world beyond sensual material existence or indeed being itself. The Outside, instead, is to be understood as an internal one. It is, as with contemporary theories of transcendence, an Outside experienced in the immanent flux of our life, typically in the particularised form of an inexplicable Other. However, it is not an Other of formal transcendence (holes of negativity); it is an Other that mediates heterogeneous differences without negative rupture, which is also to say that the Other is the fold and the fold is the Other.

\footnotetext{
${ }^{23}$ As Nathan Widder aptly puts it, "Two Routes from Hegel” in L. Tønder and L (eds.) Radical Democracy: Politics Between Abundance and Lack (2005), 43.

24 The relation is not labelled "disjunctive" until his Logic of Sense (2004).
} 
Folding as a reversal of Platonism relates to the fundamental principle of 'pure' immanence as that which is concordant, too, with the fundamental principle of Deleuze's 'transcendental empiricism': the conditions of experience are derived from experience itself. 'Pure' immanence is 'transcendental' insofar as it concerns itself with the conditions of experience, and yet still empirical insofar it concerns itself with the real to which it is immanent. The fold, as the internal/inside difference that mediates differences, is derived from our encounters with the Outside, it is the Other, to the extent that the Inside is merely that of its crease, i.e. it is derived from the Outside as an experience stored as a memory trace, a virtual force in a force relation of difference. Thus it is through the Other/Outside as an encounter that is folded into the self, and in turn folds/mediates differences, that a thing gains its meaning and sense, i.e. unfolds. One cannot be separated from the other. There is, then, no truly public-private distinction to be had, nor an ultimate stable point of departure, nor a transcendent outside, nothing truly beyond that which we live in ultimate flux that can be relied on as a pre-socio-political or extra-sociopolitical ground. Thus there is neither a subject - be that as a positive Body or a negative Being - as an external precondition of thought, meaning and action. The ' $\mathrm{I}$ ' of the subject and the identities by which it marks itself are the temporary surface effects of folding. The 'subject' is a fold. And the affect (be it pleasure or desire) is the Inside of the fold, its crease, the will of the self operating in disjunction with the Outside of the self.

\section{Deleuze, the Will to Power and Desiring-Machines}

Regarding Deleuze, the origin of the fold as a disjunctive synthesis is found and explicated in the will to power as conceptualised in his Nietzsche and Philosophy. According to Deleuze, the 'will to power' forms the crux of Nietzsche's most general project, which is "the introduction of the concepts of sense and value." ${ }^{25}$ As opposed to anthropocentric and essentialist ontologies, Nietzsche understands sense and value in expressivist terms. Nietzsche's expressionism refers to a reversal of the tactic notion that evaluations are hinged on pre-given values through which a subject appraises, judges and evaluates, holding instead that "values presuppose evaluations," or "'perspectives of appraisal," from which their own value is derived. ${ }^{26}$ In this case, evaluations are not values, but rather the "differential element," or the "mode of existence" that sense and values express and from which they arise. ${ }^{27}$ In a manner of speaking, this is simply to say that our values, judgements and sense of things express and derive from our particular being-inthe-world. However, as opposed to limiting itself to the symptomatology common to phenomenological analysis, Nietzschean critique seeks to uncover the ontogenetic force that appropriates, exploits, possesses and is expressed in the differential element itself. It seeks, in other words, a genealogy of sense.

In concerning itself with the relation between forces and our being, genealogy invariably relates to Nietzsche's rethinking of quantity and quality as related to the multiple

\footnotetext{
${ }^{25}$ Gilles Deleuze, Nietzsche and Philosophy [1962] (2006), 1.

${ }^{26}$ Ibid., 1.

27 Ibid., 2.
} 
and their respective relationship. Deleuze's basic contention is that for Nietzsche against mechanistic abstractions of unity and numerical quantity - forces can never be thought of in isolation nor as equal. ${ }^{28}$ Psychic forces of interiority (the first fold) are always in relations of inequality, continual flux and disequilibrium. Such a relation presents us with a world of "dynamic quanta," wherein forces clash with one another in such a way that one will invariably take the superior position and as such establish and subordinate inferior forces. ${ }^{29}$ It follows that a force must express itself in accordance with the other forces to which it relates. Forces do not relate via negationis, and neither are their subsequent quality determined via negationis. Or rather, forces do not contradict, they 'vice-dict' each other, corresponding through domination/submission without losing their singularity. The essence of force, then, is its "quantitative difference from other forces, which is expressed as the force's quality." ${ }^{30}$ If a force dominates over another, if it is quantitatively superior, it will have for itself the quality of being active: it commands, creates, transforms and overcomes. Conversely, an inferior force will have to submit to its superior counterpart, and as such it will only have for itself the quality of reaction. Quality, in other words, denotes the means by which a force can express itself in a given relation of quantity.

Anomalous though this may seem, the role of the Outside (as in the second fold as that which is folded in to create the third fold as continuum) in this process is to be understood by way of the inside, taken as will or drive. There must be some sort of nonsubjective compulsion assigned to forces to make them what they are, Nietzsche holds, for mere variations of power "could not feel themselves to be such: there must be present something that wants to grow and interprets the value of whatever else wants to grow." ${ }^{31}$ As opposed to the anthropomorphic sense as known by psychology, or relatedly the mechanic sense of a strict causality between cause and effect as known by classical physics, this idea of will/drive refers precisely to the differential (as the Outside that differentiates forces) and genetic (as that which determines their quality) element of force relations. The difference in quantity reflects a differential element of related forces, "which is also the genetic element of the qualities of these forces." ${ }^{32}$ The relation also involves chance according to the asynchronistic movements of history. Chance as arbitrary Outside encounters of experience (or 'haphazard conflicts' as Foucault puts it) bring forces into relation in the first instance, while "the will to power is the determining principle of this relation." 33

The Outside as encounter provides the will to power with its qualities. Qualities such as we find in a moral diktat; equal in part to Freud's reality principle as expressed and exercised by the superego against the Id and through which the ego arises as the medi-

\footnotetext{
28 Ibid., 44.

${ }^{29}$ Friedrich W. Nietzsche, The Will to Power [1901] (1968), 339.

30 Nietzsche and Philosophy, 46.

31 The Will to Power, 342.

32 Nietzsche and Philosophy, 46.

33 Ibid., 49.
} 
ated form. Unlike Freud's superego, however, Deleuze-Nietzsche's Outside qualities do not express an outside force of negation, as with the repression of the sexual Id. Rather, these Outside qualities add to and produce the Inside multiplicity/fold by compelling the evaluation and relation of forces so as to affect their means of expression or their mode of becoming. The Outside here acts as the primordial qualitative element underpinning interpretation, and in turn that which determines the qualities of force. Crucially, "these fluent, primordial and seminal qualitative elements," Deleuze warns, "must not be confused with the qualities of force." ${ }^{34}$ Whereas the quality of a force is determined by the differential of quantities, designated in terms of active and reactive forms of expression, the quality of the will to power itself is designated in terms of affirmative and negative. With this reading, action and reaction "are more like means, means or instruments of the will to power which affirms and denies, just as reactive forces are instruments of nihilism." 35

The will to power is a differential and a genetic element of psychic force relations of the self. Taking their cue from Deleuze's Difference and Repetition ${ }^{36}$ - specifically chapter 2 where the will to power as the differential-genetic is used to conceptualise the third synthesis of time and in turn as a way to revise the Freudian Oedipal process - Deleuze and Guattari's Anti-Oedipus takes up the will to power and applies it to psychoanalytic desire and politics as social-production. ${ }^{37}$ From this, it holds that the true nature of instincts cannot be inferred from their instantiation in social institutions and representations up to and including the Oedipal triangle (daddy-mommy-me). Indeed, desire is deemed 'machinic' by Deleuze and Guattari, precisely because it does not represent anything. Desire only produces in the real world and its product is reality and our experience of it. Desire produces in this vein by virtue of its folded connections with "social production" as the immanent Outside. In this way, the production of reality takes the form of an immanent causality (the cause is in the effect), in which there is no dualism or opposition between man and nature, thus: "Nature=Industry=History." 38 Desiring-production is thus "one and the same thing as social production," and so it is far from a "natural multiplicity', 'pre-symbolic libidinal flux', or predicate of power, as Butler and Grace hold. ${ }^{39}$ In short, Deleuzian desire is the will to power.

Here, the two sides of the will to power (also the first and second folds; the differential interpretation and evaluation; and the two multiplicities [virtual and actual] as they are construed in Difference and Repetition) are construed instead in terms of desiringproduction (micropolitical) and, as already mentioned, social production (macropolitical). But this distinction does not amount to an ontological dualism, such as the dualism

\footnotetext{
34 Ibid., 50.

${ }^{35}$ Ibid., 50.

${ }^{36}$ Gilles Deleuze, Difference and Repetition, chp 2.

37 To be sure, see Deleuze and Guattari, Anti-Oedipus [1972] (2004), 355. For more on the relation between Deleuze's interpretation of the will to power and its use in Anti-Oedipus, see Ronald Bogue, Deleuze and Guattari (2001), 3.

38 Gilles Deleuze and Felix Guattari, A Thousand Plateaus: Capitalism and Schizophrenia, 25.

39 Ibid., 32.
} 
between the One and the Many, "but on the contrary, of distinguishing two types of multiplicities," or rather two types of folded production that form a continuum, the third fold. ${ }^{40}$ The microscopic/micropolitical and the macroscopic/macropolitical are of the same nature, the ontological plane - Univocal or Oneness of Being - differing only in regime as distinct magnitudes of expression from the virtual into the actual, or the incompossible into the possible. Many have interpreted the One of immanence in terms of Platonist emanation. Deleuze does indeed claim that all modalities and differences, all individuals and substances, are expressions of a single ontological substance. ${ }^{41}$ That is to say, there is no difference of category, of substance and of form, between the senses of the word 'Being', e.g. for-itself and in-itself, or, ultimately, the subject and object. But, and this is the crucial point, the single ontological substance relates to itself through a series of disjunctive differentials or folds between and within multiplicities as distinguishable regimes, and it is only by virtue of this differential that it can create differenciated or qualitative distinctions in Being, i.e. beings. The single and same sense is difference initself and thus the expression of the multiple, as opposed to the monotony of the One. Thus, the difference in regime, or the difference between the Inside and Outside - which can be understood as an epistemological, even ontic difference - does not exclude the immanence of each to the other. There are "only multiplicities of multiplicities forming a single assemblage, operating in the same assemblage." ${ }^{42}$

The assemblage refers to the relation between multiplicities and as such is broadly understood as a thoroughly heterogeneous ensemble that synthesises and thus consists of divergent divergences, be they biological, social, machinic, gnoseological or imaginary, often underpinned and partly shaped by a broader socio-historical substratum. Each assemblage of desire has elements or multiplicities of several kinds, with different elements interpenetrating one another. The multiplicity of the multiplicity, the great 'third' fold that connects Inside and Outside, establishes an assemblage as a continuum. The principle of syntheses, the great 'third' fold of the will to power, is construed here through the concept of Body without Organs (BwO). In accordance with its broader definition as the plane of immanence or the virtual prior to its actualised expression, the $\mathrm{BwO}$ in this context marks the zero point of virtual intensities or forces. In relating the BwO to desire, it is important to distinguish it from Freud's death instinct.

The death instinct implies a kind of thermodynamic reference or a process of repetitive compulsion to seek satisfaction from the same object (the obsessional neurotic return of the same), matching a particular memory trace of previous satisfaction (such as nipple-mouth). ${ }^{43}$ In contrast, the $\mathrm{BwO}$ represents an interruption in this process, an antiproduction, wherein the subject is open to a virtual past that contains a limitless variety of modes or an incompossibility of modes of satisfaction. By incompossibility, I mean

\footnotetext{
40 Gilles Deleuze, Bergsonism (1991), 39.

${ }^{41}$ Difference and Repetition, 45.

42 A Thousand Plateaus, 38.

43 Sigmund Freud, "On the Pleasure and the Reality Principle", in Ana Freud (ed.) The Essential Freud. (2005), 505-517.
} 
multiple and seemingly contradictory possibilities that virtually co-exist in the self without negating each other, by virtue of disjunction. The libidinal or affective connection is never merely a choice between one thing and another, 'this or that', 'either/or' but a momentary choice among a multitude of possibilities, i.e. 'either...or...or' ${ }^{44}$ Thus following Deleuze's rendering of Nietzsche's notion of the 'eternal return' as the continual return of the enigmatic differenciator, neurotic repetition is repetition of difference as opposed to identity, afforded by intelligence and institutions functioning with but outside instinct. ${ }^{45}$ Each time the representation of sense-presentations in the form of the ' $\mathrm{I}$ ' arises - e.g., I feel angry; I am a sensitive soul; I love tea - one is merely actualising a variant, and a new configuration of the incompossible relation of forces as derived from the Outside and as found in the spatiotemporal virtual self. Each arrival of the conjunctive ' $\mathrm{I}$ ' is different to the one that preceded it no matter how repetitive the identityperformance to which the ' $\mathrm{I}$ ' relates. The disjunctive thus serves to break the self into multiple subjectivities, as in a fractured $I$.

There is another mode of anti-production, however. In this other mode, the $\mathrm{BwO}$ is subjected to an exclusive disjunction. It is exclusive for it refers to a relation that forces a choice between one thing or another. It is here that we find repression. Now, Foucault could be forgiven for shying away and bemoaning any use of the concept 'repression'. Though certainly not a unified concept, it can be loosely described as depending on two basic postulates: the idea of a unified subject with essential attributes that are then repressed and a central power that does the repressing via outright negation. Deleuze clearly avoids reference to a unified subject, seeing instead the subject as perpetually and always-already fractured ' $\mathrm{I}$ ', a disjunctive assemblage of force relations. And though negation is certainly the intention of numerous repressive powers, Deleuze holds that repression never quite functions in that way. Being equivalent to Nietzschean evaluation, it refers to the primordial Outside qualities that redirect or reroute the productive flows and connections of desire, in turn codifying them into distinct types. Or rather, to re-use the language of Deleuze's Nietzsche from whence this concept derives, it means altering the form of expression of forces. Once more, there is no negation in this relation. In redirecting the forces of desire, as opposed to negating them outright, repression produces new assemblages of desire. That is its critical power, the power to produce modes of subjectification.

The fundamental argument of Anti-Oedipus is that such repression is central to the operation of capitalism. It aids capitalism in insulating itself from its own interior limit. This limit is the schizo-subject (a subject open to multiple or incompossible modes of libidinal connection) that it produces by decoding and deterritorialising. Capitalism releases polyvocal desire by exchanging qualitative or evaluative codes of pre-industrial society (good vs. evil) with the abstract quantities of the axiomatic of capital (the value

${ }^{44}$ This resembles Freud's 'polymorphous perversity' of the infantile (pre-ego) unconscious in that pleasure can be found or taken almost anywhere. See Eugene Holland, "Deleuze and Psychoanalysis", in Daniel W. Smith and Henry Somers-Hall (eds.) The Cambridge Companion to Deleuze (2012), 332. ${ }^{45}$ Anti-Oedipus, 10. 
of exchange). And yet, post-industrial consumer societies, Deleuze and Guattari contend, are highly dependent on 'neurotic' subjects who, for instance, frivolously consume to sustain economic growth, or feel guilt for not paying a debt to sustain creditors, or who are 'stable' enough to retain confidence in markets and so forth. Thus capitalism embarks on a second movement or re-territorialisation, under which it seeks to re-use qualitative codes to effectuate the desired subjectivity. Re-territorialisation is primarily achieved through the family. For under capitalism, the family is privatised and placed outside the social field. Such placing is capitalism's greatest social fortune, in that it is the condition under which the entire social field can be applied to the family. Through the family, Oedipal complex is employed as a fiction that separates desire from its productive force of connection, thus creating the conditions of the required neuroses (akin to the topology of Nietzsche's 'internalisation of man' as conceptualised by Deleuze). ${ }^{46}$ The judge, the policeman and the teacher do not represent and re-enact the father. The father represents and re-enacts the judge, the policeman and the teacher. The repressive process engenders a split at the centre of the subject between his abstract ideal, preceded by the potential of the axiomatic, and the codes by which he lives. ${ }^{47}$

Modes of repression and disciplinary tactics applied to multiple layers of our intersubjective being shape our sense of self on an unconscious level, in turn reifying a pervading order (the second fold) or at least establishing what we can perhaps call manageable 'subjects of convenience'. Desire is always-already assembled and directed by sociopolitical and economic forms of organisation as its immanent Outside. This notion of unconscious desire leaves us with the question of agency-based resistance. The point, for Deleuze and Guattari, is that it is precisely by virtue of being the agentic and affective pivot point of such forms that desire as will to power has the capability to surmount them; and, indeed, to surmount the general categories of standard politics altogether. If we are constituted at this virtual affective level (desire), albeit in accordance with the actual/macro, then it is to the virtual, first and foremost, that we must seek political subversion.

We can never reach the virtual directly either in action or thought, for all action and thought is an actualised expression of the virtual under the form of an extension that necessarily cancels out the intensive through which the virtual proceeds into the actual. The unconscious, in other words, remains unconscious and can only be accessed and affected indirectly. In terms of the indirect, there are certain techniques or tactics that act as new Outside encounters. These encounters affect the virtual by altering the forcerelations of the virtual unconscious, thus changing the direction, speed, intensity and sensibility of thought. The force relations of the self that continually define and shape the ego can be affected and recomposed through our own created encounters. In recomposing these forces, one can disrupt all that relies on a specific configuration of them. Such tactical folding has the potential to reconfigure and release captured intensities or actualise new ones, to transform the subjectivities upon which the socio-political relies.

${ }^{46}$ Nietzsche and Philosophy, 107-125.

${ }^{47}$ Anti-Oedipus, 334. 
The disjunctive fold - the differenciator, dark precursor or $\mathrm{BwO}$ - through which the virtual is related to a plane of organisation, creates the very excess through which this can be technically realised. For it is by the disjunctive that there are a variety, an incompossibility of virtual-desiring virtualities waiting at any given time to be actualised and reshaped through various techniques that create new encounters across a range of personal, social, and political strata. As we will come to see, this strongly resonates with Foucault's own ethics of the care of the self, for it regards techniques and practices that opens paths of resistance, without reference to a real or formal transcendence that would contradict the immanent ontology upon which this concept of desire is perched. Where there is power, there is resistance.

\section{Foucault, Power-Knowledge and Pleasure}

We find this conceptual schema of 'pure' immanence with its three levels of folding in Foucault, albeit within the context of the three axes of Foucault's genealogy: discourse, power and ethics; and of course, in a different development order.

Foucault's first axis (including works such as The Order of Things and the Archaeology of Knowledge) studies discourse as a mode of inquiry that objectifies the speaking subject in general grammar, philology, and linguistics. In this sense, it signifies an ontological engagement with folded relations exterior to the self, exterior though interiorized constructions of linguistic meaning, i.e. the second fold. Indeed, in outlining discursive formations and their inner workings, Foucault dismisses four initial hypotheses on the basis that, in each case, the 'logic of dispersion' undermines the assumption of internal consistency. Dispersion, in this instance, is understood as not merely a scattering of elements in an open space, but 'a difference within the convergence of heterogeneous domains' ${ }^{48}$ With such an understanding, it holds that the concept is inseparable from disjunctive syntheses, in which, once more, differences are not collapsed into a unity (as with dialectical thinking), but rather form the intersection where linguistically signifiable unities of knowledge can appear. For this reason, Foucault argues that a discursive formation is characterised not by privileged objects but by the way it forms objects that are in fact highly dispersed or mutually exclusive without having to modify itself. When one speaks of a system of formation, "one does not only mean the juxtaposition, coexistence, or interaction of heterogeneous elements....but also the relation that is established between them - and in a well determined form - by discursive practice." 49

Following this analysis of discourse, Foucault was soon to recognise that man is "equally placed in power relations that are very complex." ${ }^{50}$ While this signifies a shift in the form of analysis, the disjunctive logic remains the same, though now it explicitly meets force as its Outside. Thus, when Foucault presents an analytic of "power without the king," he is directly referring to, as he puts it himself, a "multiplicity of force rela-

\footnotetext{
48 See Widder, Foucault and Power Revisited, 416.

${ }^{49}$ Michel Foucault, The Archaeology of Knowledge [1969] (2002), 80-1.

${ }^{50}$ Michel Foucault, "The Subject and Power", in James D. Faubion (ed.) Michele Foucault: Power: Essential Works of Foucault 1954-1984 (2001), 327.
} 
tions" or "the [virtual] moving substrate of relations between forces, which by virtue of their inequality, constantly engender states of power," such that every relation between forces is a power relation. ${ }^{51}$ In being the virtual double our Outside of discursive knowledge, it holds that power shares an intimate connection with it. Whereas force is, as Deleuze quite aptly puts it, diagrammatic, in that it is "detached from any specific use," knowledge concerns formed matters or substances and formalised functions, "divided up segment by segment according to the two great formal conditions of seeing and speaking, light and language." ${ }^{52}$ Knowledge in this way represents a relatively rigid segmentarity, as in a segment inscribed on a virtual plane of immanent incompossibility that forces it into actualised differentations, i.e. something identifiable and seemingly binary, or simply, an exclusive disjunction. The difference in nature between power and knowledge, however, does not prevent a mutual immanence or double-conditioning within the remit of folded Univocity. As before, they differ only in regime; and we see that the one continually affects the other, such that to isolate one as the ultimate cause is to enact a radical abstraction. Here, truth is "linked in a circular relation with systems of power that produce and sustain it, and to effects of power which it induces and which extend it - a 'régime' of truth'." ${ }^{53}$ Hence: power-knowledge.

The echoes here of Nietzsche's concept of force, as conceptualised by Deleuze, are far from coincidental. On numerous occasions we find Foucault directly linking his idea of power relations with Nietzsche's concept of force, or as Foucault puts it in 'Truth and Juridical Forms', the idea that 'knowledge will finally appear as the "spark between two swords"'; there is no form of "congruence, love, unity, and pacification," but rather "hatred, struggle, power relations." ${ }^{54}$ More significant is Foucault's acknowledgment of the influence of Deleuze's "superb book about Nietzsche," and Deleuze and Guattari's AntiOedipus - which, as I argued, relies on Deleuze's concept of the will to power as developed in Nietzsche and Philosophy - in the construction of his understanding of power. ${ }^{55}$ Deleuze's Nietzsche thus comes to influence Foucault in two ways. The first is direct, and comes by way of Nietzsche and Philosophy. The second is indirect, and comes by way of Anti-Oedipus.

The use of Deleuze in this way is quite haphazard, and is thus deserving of clarification. Foucault's use of disjunction in Archaeology of Knowledge [1969] came ten years after

\footnotetext{
51 The Will to Truth, 1 and 2.

${ }^{52}$ Foucault, 61.

${ }^{53}$ Michel Foucault, "Truth and Power", in Colin Gordon (ed.) Power/Knowledge: Selected Interviews and Other Writings 1972-1977 (1988), 133. This stands in contrast to Peter Dews, Logics of Disintegration: Post-Structuralist Thought and the Claims of Critical Theory (2007), 211 and 13., who holds that Foucault "presents power as a precondition of knowledge, rather than knowledge as a precondition of power," such that his immanent formulation "appears to attribute a certain ontological priority to power."

${ }_{54}$ Michel Foucault, "Truth and Juridical Forms", in James D. Faubion (ed.) Michele Foucault: Power: Essential Works of Foucault 1954-1984 (2001), 12.

55 Foucault, Structuralism and Post-Structuralism, 445. For more on the influence of Deleuze's Nietzschean conception of force on Foucault, see Hans Sluga, "Foucault's Encounter with Heidegger and Nietzsche", in Gary Gutting (ed.) The Cambridge Companion to Foucault (2003), 224-6.
} 
the publication of Deleuze's Nietzsche and Philosophy [1962]. Though there are no direct references to Deleuze's Nietzsche in Archaeology, Foucault does directly employ a reading of Nietzsche's genealogy that is strikingly similar. And given Foucault's comments on Nietzsche and Philosophy as per above, we can infer (with some reservation) that Foucault did draw from it. Beyond inference, what is certain is that Nietzsche and Philosophy and Anti-Oedipus (1972), alongside the events in France of May 1968, ${ }^{56}$ provoked Foucault's conceptual inclusion of power as an Outside force relation; as exemplified in Discipline and Punish (1975) and the first volume of the History of Sexuality, The Will to Truth (1980). Indeed, Foucault directly references Anti-Oedipus as the inspiration for his concept of power. ${ }^{57}$

The chronology above relates to a principle difference between Foucault and Deleuze's respective use of Nietzschean force as related to the fold. It regards the type of force-relations in question. In Deleuze's earlier works (the ones published prior to AntiOedipus) the force-relations in question are primarily psychic, or unconscious in the Bergsonian vein of a virtual multiplicity - thus signifying the first fold. Though still virtual, in that it refers to a real relation without an actual extended existence, Foucault's use of force in his early to middle works concerns the socio-political and exterior - thus signifying the second fold. That is, where Deleuze's oeuvre starts out with an analysis of what I have identified as the first fold, Foucault's oeuvre begins and develops up to his middle period the second fold and the folded relations therein. Specifically, the second fold is developed in terms of discursive knowledge and its relation to power.

Though the first fold remains somewhat absent in Foucault's early to middle works, we find in them a conceptual incorporation that bears on the third; I say 'although', for the third fold is the connection between the first and second, and thus presupposes the existence of both. First, the third fold exists as a principle underpinning the relation between knowledge and power, in terms of double-conditioning. Second, the third fold is developed in Foucault's discussion of power in Will to Truth. Specifically, regarding the question of macro-political strategy. Here, Foucault argues that though power-relations are not static forms of distribution, they eventually enter into and correspond to an overall strategy, such as bio-power, simultaneously gaining support "from precise and tenuous relations serving, not as its point of application or final outcome, but as its prop and anchor point." ${ }^{58}$ As with power-knowledge, we are presented with 'doubleconditioning' though now in a context acutely akin to Deleuze and Guattari's concept of the assemblage as a casually immanent relation, i.e. the relation between the microscopic and macroscopic, wherein the two domains reinforce and undermine each other via a relation of disjunction. Foucault tries to capture this entire process through the concept of the dispositif, as "a thoroughly heterogeneous ensemble consisting of discourses, institutions, architectural forms, regulatory decisions, laws, administrative measures, scien-

\footnotetext{
56 See James Miller, The Passion of Michel Foucault (1994), pp. 175-184.

57 See Foucault, Discipline and Punish: The Birth of the Prison (London: Penguin, 1991), 24; and 309n. 2.

${ }^{58}$ Foucault, The Will to Knowledge, 99.
} 
tific statements, philosophical, moral and philanthropic propositions," and so forth. ${ }^{59}$ It is the system of relations that can be established between these elements, as with the assemblage. The two concepts are, for the most part, interchangeable.

Now, this raises the question of the difference between the exterior and the Outside. The exterior refers to that which sits outside of the self as an interior. Though the Outside refers to that which is immanently Outside the self, it also refers to that which is immanently Outside of any relation, subjective or otherwise. Discourse has its own Outside understood as force or power-relations, though that does not render discourse as the interior self. Thus when I speak of an Inside self, the 'Insideness' is not a concept exclusive to the self, whereas its interiority is. Discourse and power are still, at this point of Foucault's thinking, primarily of the exterior. The interior self of the first fold finally appears in Foucault's last works, which he self-classified as a turn to ethics / third axis of genealogy. The self takes centre-stage.

Given the role of disjunction, it is unsurprising to see that resistance, as with Deleuze, concerns an ethical practice of the self that can take advantage of the dispersion or disjunctive excess underpinning a dispositif. This notion of resistance relates to Foucault's initial construction of ethics as the third axis of genealogy by which the individual constitutes and recognises him/herself as a subject (self-subjection), in particular a subject of sexuality, "how men have learned to recognize themselves as subjects of 'sexuality'."'00 Such a formation speaks to a retroactive consumption of the very discursive identities and norms produced and thrown up by virtual processes of force relations in conjunction with strategies of bio-power. In order for the recognition or identification with a subject position to remain somewhat stable, or at least to take effect, it requires practices of the self that serve to reinforce it, such that ethics involves "technologies of the self." ${ }^{\prime 1}$ Thus, when, in The Subject and Power, Foucault declares that "it is not power, but the subject, that is the general theme of my research," he is in fact referring to the immanent double-conditioning process by which the subject and the identities by which it attempts to sustain itself are generated. ${ }^{62}$ There is no privileged subject as the pre-condition of thought, meaning and action, but rather a subject as an immanent effect. But given that it is an effect of a process of immanent disjunction, which as we saw speaks to a fallible unity of incompossible elements that are related without being subsumed (in which any variant of this relation can be actualised at any point in time) it follows that a certain excess is built into the relation. It is an excess that propels and allows for the selfovercoming of the condition, turning it into a process. Taking advantage of this excess through technologies of the self is equivalent to refolding. Ethical practice, then, can be turned around/ refolded so as to subvert a self-identified subject position, a new interior folding.

\footnotetext{
${ }^{59}$ Michel Foucault, "The Confession of the Flesh," Power/Knowledge: Selected Interviews and Other Writings 1972-1977, ed. Colin Gordon (1980), 194.

${ }^{60}$ Michel Foucault, The Subject and Power, 327.

${ }^{61}$ Ibid., 327.

62 Ibid., 327.
} 
In exploring this, Foucault turns to the classical Greeks as, for him, they present the beguiling idea of life as material for a work of art. As Foucault puts it, the ethical substance in ancient Greece - aphrodisia - is a nexus of forces that links together rules, techniques and institutions, along with "acts, pleasures, and desires," operating "'beneath the codes and rules" of knowledge and power, unfolding and merging with them, creating new foldings (and being created in the process), whose "variations constitute irreducible modes of subjectivation." ${ }^{63}$ The object for moral reflection is not the act itself, or desire, or even pleasure, but "more the dynamics that joined all three in a circular fashion." ${ }^{64}$ In this sense, the ancient Greeks "folded force," they "made it relate back to itself," and far from ignoring interiority, individuality or subjectivity, "they invented the subject, but only as a derivative rule of free men," as Deleuze puts it. ${ }^{65}$

But does this interiority as Inside fold have substantial affectivity as it does in Deleuze? Is it not the case that where Foucault politicises the fold (that is the dispersion/disjunction at the heart of a discursive formation) through the addition of force, which speaks to a topological relationship in which the Inside-interiority is formed by a crease in the Outside, Deleuze makes desire the inside in general, or "the mobile connection between the inside and the two other features, the outside and strata?" ${ }^{66}$ Foucault does not completely neglect the body, or indeed the affective as related to the body. Indeed, in the Will to Truth, Foucault goes on to identify two routes down which the power over life proceeded: the first "anatomic" and the second "biological." ${ }^{67}$ However as is oft-commented, Foucault does not explore the interiority of the affective body as a virtual multiplicity of force relations in and of itself.

Regarding affective interiority, this came later in the final stage of Foucault's thought. In the first volume of The History of Sexuality - which I would argue is the pivot point between the second and third axis ${ }^{68}$ - Foucault speaks of a "sensualization of power and a gain of pleasure," in which the pleasure discovered feeds back to the power that encircled it. ${ }^{69}$ There is a certain "pleasure that comes of exercising a power that questions, monitors, watches, spies, searches out, palpates, brings to light." ${ }^{70}$ He also speaks of a "pleasure that kindles at having to evade this power, flee from it, fool it, or travesty it....power asserting itself in the pleasure of showing off, scandalizing, or resisting." ${ }^{71}$ Thus, even though power captures pleasure, and finds pleasure in its capturing, pleas-

\footnotetext{
${ }^{63}$ Michel Foucault, The Use of Pleasure: The History of Sexuality Volume 2. Trans Robert Hurley [1984] (1992), 43.

64 Ibid., 43.

65 Foucault, 84.

${ }^{66}$ Deleuze, Two Regimes of Madness, 264.

${ }^{67}$ Foucault, The Will to Truth, 139. It was by this particular focus on the body that sex and 'desire' was established as a discourse, in turn creating a permanent and visible reality that effectively served to and arguably still does - regulate self-to-self relations.

68 See Jon Simons, Foucault $\mathcal{E}$ the political (1995), 34.

69 The Will to Truth, 44.

70 Ibid., 44.

71 Ibid., 45.
} 
ure also offers the 'possibility of resistance', which is to say that there are 'perpetual spirals of power and pleasure'. The notion of spirals of power and pleasure offers an affective and agentic site that need not refer to an essentialist factor sitting outside of the immanent process of subjectivity. ${ }^{72}$ Pleasure, in other words, has its reactive and active moments; when of the former, it is the most effective method of re-folding-acts of pleasure over analyses of desire.

\section{Politico-Ethical (Re)Considerations}

I have thus far traced three prominent lines of convergence between Deleuze and Foucault:

Disjunctive (folding of) syntheses, in which differences - and the Outside and Inside - are related without for all that being collapsed into a higher unity or dissolving into separate ontological orders. In Deleuze, this is understood interchangeably in terms of quantitative and qualitative forces; micro and macro multiplicities/politics; desiring- and social-production; and the assemblage. In Foucault, this is understood interchangeably in terms of discursive dispersion; power as the virtual substrate of force relations; double-conditioning of the micro/macro; and the dispositif.

Political resistance as an ethics of the self or ethical practice, wherein one takes advantage of the dispersion or excess that results from disjunction, refolding or folding back, such that resistance need not refer to either a real (positive Body) or formal (negativity) transcendence that would negate immanence. In Deleuze this is understood in terms of becoming a Body without Organs. In Foucault, this is understood in terms of a care of the self.

The use of the body and affectivity as the inside of the fold or power. In Deleuze this is understood in terms of desire. In Foucault this is understood in terms of pleasure.

Recognising the convergence is incredibly noteworthy, for it undermines those who interpret the immediate lines of divergence between Deleuze and Foucault as occurring in the understanding of subjectivity and (its relation to) power. The former is alleged of committing to a mechanistic negative conception of power with a positive subject as its correlate that stands opposed to the latter's positive relational conception of power- or vice versa depending on the interpretation. The ontological consistency in turn leads to a workable consistency regarding the question of affectivity and politico-ethical resistance. Disjunctive syntheses of force-relations (power) contain an excess as opportune discontinuities. As this synthetic concept is at the centre of the power/interior-affective network itself - it is how it functions - it follows that resistance is built into. It is through the excess that one may 'refold'.

There remains, however, the question of ethical differentiation. The question is highly heuristic in that it bears on the critical ontic difference between pleasure and desire and their respective efficacy. From genealogy - be that Deleuzian or Foucauldian - it follows that there is no objective, 'higher' analogical vantage point/no transcendent Outside to which we can refer and no stable vantage point of thought $=$ no morality with a univer-

72 Ibid., 156 and 45 
sal ontological or epistemic basis. What then? To remain consistent Deleuze and Foucault once again follow Nietzsche's genealogy, and to some extent Spinoza's Ethics (the two are sewn together in a way that makes for a partly indiscernible union). Nietzsche and Spinoza both overturn moral questions that imply essence via potentiality and in reference to external primary analogates (i.e. what should I do?) in favour of ethical ones. The ethical concerns a reference to Being in terms of existence and its capability and the power of effectuation (i.e. what can I do?). That is, the consistency between Univocal immanence and ethics so conceived is found in the fact that such ethical questions are grounded in the immanent modes of existence themselves, with reference to the degree of power, the processes of actualisation, subjectification and stratification, i.e., what mode of existence does a particular thought, action or feeling imply? From where does it derive and what does it express? How is a mode determined? Modes of existence or expressions of the virtual, in other words, should be evaluated according to the intensive criteria of power in its qualitative and typological senses. Affective expression is evaluated according to its determining will to power or type of pleasure, in terms of active and reactive wills to power (and capacities), with one ultimately affirming life in its difference of creative becoming and the other negating it.

Deleuze and Foucault differ in terms of preferred language for conceptualising this affective-virtual multiplicity. Foucault opts for 'pleasure' for it avoids psychoanalytic idealism and the myth that there is a desire free from power. Pleasure is, for Foucault, a question of quantity, whereas desire is a question of quality. Either we are concerned with merely differentiating expressed modes corresponding to actions based on efficacy and sustenance (the 'too much' and 'too little' of pleasure), or we are concerned with moralising an action by qualifying its object of interest through recourse to a subjective determining drive (the 'pure' kind and the 'perverted' kind of desire) as that which reveals the truth and value of the self. Even when recognising that Deleuze and Guattari employ a concept of desire distinct from psychanalytic idealism that treats desire as a permanent a priori form subject to permanent a priori judgements, Foucault remains sceptical. The word itself is what appears to be problematic. Language exists in a discursive network after all, particularly conceptual language. Thus, despite any internal conceptual subversions, the use of a word entails a subtle network of power-relations capable of invoking and/or inviting un/intended misuses. As Foucault puts it:

Deleuze and Guattari obviously use the notion in a completely different way. But the problem I have is that I'm not sure if, through this very word, despite its different meaning, we don't run the risk, despite Deleuze and Guattari's intention, of allowing some of the medico-psychological presuppositions [prises] that were built into desire, in its traditional sense, to be reintroduced..$^{73}$

Deleuze agrees that desire and power are synonymous in that they are mutually constituted in a discursive domain that entails a power-knowledge network. However,

\footnotetext{
${ }^{73}$ As quoted in Michel Foucault, Nicolae Morar and Daniel W. Smith "The Gay Science," Critical Inquiry, Vol. 37:3 (2011), 389.
} 
Deleuze goes on to say that pleasure too is problematic, especially as a resistive concept. It is less a discursive concern, as more a topological one. Pleasure can signal an effect or be secondary to a process in which desire is already assembled. Pleasure, Deleuze contends, "seems to me to be the only means for a person or a subject to orientate themselves in a process that exceeds them. It is a re-territorialisation. From my point of view, this is precisely how desire is brought under the law of lack and with the norm of pleasure," and thus pleasure sits "on the side of strata and organization...it is in the same breath that desire is presented as internally submitting to the law and outwardly regulated by pleasures." 74 The critical point is that a reactively assembled desire can find a sort of pleasure in its own repression or in the punishment of others by way ressentiment. Thus pleasure is not inherently subversive or free from discursive restraint.

Two points should be made here. First, it is plausible that Deleuze's subverted use of desire is one that is possible and exists by virtue of the very disjunctive excesses of the asignifying chain underpinning discourse. That is, the subverted use of the concept itself is a prime instance of Foucauldian resistance through discursive power relations. Second, Deleuze's critique of pleasure downplays the 'active' and 'reactive' distinction Foucault makes in it. Though seemingly qualitative, active and reactive pleasures refer to the quantity of the pleasurable activity itself and how that relates to various modes of being. Like Deleuzian desire, it stands that pleasure in repression can be a 'reactive' pleasure; that an active or affirmative pleasure is congruent with an active and affirmative 'Deleuzian' desire. What is the true ontological difference, after all, between desire and pleasure as affective insides of power? And so, what are Deleuze and Foucault if not vrais amis?

But these are strictly suggestive remarks, the potential of which warrants a vast conceptual effort to realise and judge; this is the reservatio finalis. There is no obvious or immediate resolution to this ontic disagreement beyond the plausible. But given the ontological affinity between Deleuze and Foucault, this difference and the mutual critique it entails can no longer be couched in terms familiar to the literature thus far. Future discussions and debates should start from the acknowledgement that 'desire' in Deleuze and 'pleasure' in Foucault are short hands for an affective inside to an immanent and relational understanding of subjectificating powers, the conceptualisation of which is indebted to Nietzsche; and that both concepts remain problematic. It is only by explicating the true lines of convergence between Deleuze and Foucault that we can open a clearer discussion vis-à-vis pleasure and desire. Ultimately, we should dismiss the idea that Deleuze and Foucault cannot be mutually engaged when considering ethicopolitical and agentic/affective questions.

\section{References}

Badiou, Alain, Deleuze: The Clamor of Being. London: University of Minnesota Press, 2000.

74 Deleuze, Desire and Pleasure, 131. 
Beckman, Frida, Between Desire and Pleasure: a Deleuzian Theory of Sexuality. Edinburgh: Edinburgh University Press, 2013.

Best, Steve and Kellner, Douglas, Postmodern Theory: Critical Interrogations. Basingstoke: Palgrave Macmillan, 1991.

Beth Mader, Mary, Sleights of Reason: Norm, Bisexuality, Development. Albany: State University of New York Press, 2011.

Butler, Judith, The Psychic Life of Power: Theories in Subjection. Stanford: Stanford University Press, 1997.

Butler, Judith, Subjects of Desire: Hegelian Reflections in Twentieth-Century France. New York: Columbia University Press, [1987] 2012.

Deleuze, Gilles, Logic of Sense. London: Continuum, [1969] 2004.

Deleuze, Giles, The Fold: Leibniz and the Baroque. London: Continuum, [1988] 2006.

Deleuze, Gilles, Nietzsche and Philosophy. London: Continuum, [1962] 2006.

Deleuze, Gilles, "Desire and Pleasure" in D. Lapoujade (ed.) Two Regimes of Madness. New York: Semiotext(e), 2007.

Deleuze, Gilles and Guattari, Felix, Anti-Oedipus: Capitalism and Schizophrenia. London: Continuum, [1972] 2004.

Deleuze, Gilles and Guattari, Felix. A Thousand Plateaus: Capitalism and Schizophrenia. London: Continuum, [1980] 2004.

Dews, Peter, Logics of Disintegration: Post-Structuralist Thought and the Claims of Critical Theory. London: Verso, 2007.

Eribon, Didier, Michel Foucault. London: Faber \& Faber, 1992.

Foucault, Michel, "The Confession of the Flesh" in Power/Knowledge: Selected Interviews and Other Writings 1972-1977, ed. Colin Gordon. New York: Vintage Books, 1980.

Foucault, Michel, "Truth and Power", Power/Knowledge: Selected Interviews and Other Writings 1972-1977, ed. Colin Gordon. New York: Vintage Books, 1988.

Foucault, Michel, Discipline and Punish: The Birth of the Prison. London: Penguin, [1975] 1991.

Foucault, Michel, The Use of Pleasure: The History of Sexuality Volume 2. Trans Robert Hurley. London: Penguin, [1984] 1992.

Foucault, Michel, The Will to knowledge: The History of Sexuality: Volume One. London: Penguin, [1978] 1998.

Foucault, Michel, "Structuralism and Post-structuralism", in Michel Foucault: Aesthetics: Essential works of Foucault 1954-1984, ed. James. D. Faubion. London: Penguin Books, 2000.

Foucault, Michel, "The Subject and Power", in Michele Foucault: Power: Essential Works of Foucault 1954-1984, ed. James D. Faubion. London: Penguin Books, 2001.

Foucault, Michel, "Truth and Juridical Forms", in Michele Foucault: Power: Essential Works of Foucault 1954-1984, ed. James D. Faubion. London: Penguin Books, 2001.

Foucault, Michel, The Archaeology of Knowledge. London: Penguin, [1969] 2002.

Foucault, Michel, et al. “The Gay Science," Critical Inquiry, Vol. 37: 3, (2011), 389.

Farrell Fox, Nik, The New Sartre: Explorations in Postmodernism. London: Continuum, 2003 
Freud, Sigmund, "On the Pleasure and the Reality Principle", in The Essential Freud, ed. Ana Freud. London: Vintage, 2005, 505-517.

Grace, Wendy, "Faux Amis: Foucault and Deleuze on Sexuality and Desire", Critical Inquiry, 36:1, 2014. DOI: 10.1086/606122

Habermas, Jürgen, The Philosophical Discourses of Modernity. Cambridge: The MIT Press, 1987 Hardt, Michael and Negri, Antonio, Empire. London: Harvard University Press, 2000.

Hendley, Steve, Reason and Relativism: A Sartrean Investigation. New York: State University of New York Press, 1991.

Holland, Eugene, "Deleuze and Psychoanalysis", in The Cambridge Companion to Deleuze, Daniel W. Smith and Henry Somers-Hall. Cambridge: Cambridge University Press, 2012.

McCumber, John, Time and Philosophy: A History of Continental Thought. Durham: Acumen, 2011.

Miller, James, The Passion of Michel Foucault. London: Flamingo, 1994.

Nietzsche, W. Friedrich, The Will to Power. New York: Vintage Books, [1901] 1968.

Olssen, Mark, Michel Foucault: Materialism and Education. London: Paradigm, 2006.

Racevskis, Karlis, Michel Foucault, Rameau's nephew and the question of identity, in The Final Foucault, eds. James Bernauer and David Rasmussen. Cambridge: MIT Press, 1991

Simons, Jon, Foucault \& the political. London: Routledge, 1995.

Sluga, Hans, "Foucault's Encounter with Heidegger and Nietzsche", in The Cambridge Companion to Foucault, ed. Gary Gutting. Cambridge: Cambridge University Press, 2003.

Widder, Nathan, "Foucault and Power Revisited", European Journal of Political Theory, 3:4, (2004), 411-432. DOI: 10.117721474885104045913

Widder, Nathan, "Two Routes from Hegel" in Radical Democracy: Politics Between Abundance and Lack, eds. L. Tønder and L. Manchester, Manchester University Press, 2005.

Wolin, Richard, The Seduction of Unreason: The Intellectual Romance with Fascism, from Nietzsche to Postmodernism. Oxford: Princeton University Press, 2004.

Žižek, Slavoj, The Ticklish Subject: The Absent Centre of Political Ontology. London: Verso, 1999.

Žižek, Slavoj, Bodies without Organs: On Deleuze and Consequences. London: Routledge, 2012

\section{Author info}

Christian Gilliam, PhD Researcher Development Officer Department of Philosophy University of Surrey Great Britain vrlnbsch@memphis.edu 